\title{
Inflammatory bowel disease: Progress toward a gene
}

\author{
David A van Heel MRCP ${ }^{1,2}$, Jack Satsangi DPhil MRCP ${ }^{1,2}$, Alisoun H Carey PhD ${ }^{3}$, Derek P Jewell DPhil FRCP ${ }^{2}$
}

DA van Heel, J Satsangi, AH Carey, DP Jewell. Inflammatory bowel disease: Progress toward a gene. Can J Gastroenterol 2000;14(3):207-218. The pathogenesis of ulcerative colitis (UC) and Crohn's disease (CD) is still unknown, but the importance of genetic susceptibility has been clearly shown by epidemiological data from family and twin studies. Linkage studies have identified two susceptibility loci for inflammatory bowel disease (IBD) on chromosomes 12 and 16. Importantly, these linkages have been replicated by independent investigators, and studies of positional candidates within these regions continue, together with fine mapping strategies. Regions of 'suggestive' linkage on chromosomes 1, 3, 4, 6, 7, 10, 22 and $X$ have also been reported in individual studies. Other important candidate genes investigated include the interleukin-1 receptor antagonist, MUC3 and genes of the human leukocyte antigen (HLA) system. The apparently conflicting data in different studies from around the world may be explained by ethnic differences, case mix and genetic heterogeneity. Replicated class II HLA associations include HLA DRB1*0103 and DR2 (DRB1*1502), involved in UC susceptibility, and HLA DRB1*03 and DR4 as resistance alleles for CD and UC respectively.

Animal studies have provided insights from targeted mutations and quantitative trait locus analysis. The goals of continuing research include narrowing the regions of linkages and analysis of candidate genes, and possibly the application of newly developed methods using single nucleotide polymorphisms. Advances in IBD genetics hold the potential to provide knowledge about the disease pathogenesis at the molecular level, with ensuing benefits for clinical practice.

Key Words: Colitis; Crohn's disease; Genetics; Inflammatory bowel disease; Review; Ulcerative colitis.

\section{Maladie inflammatoire de l'intestin : Gène en vue}

RÉSUMÉ : La pathogenèse de la colite ulcéreuse (CU) de la maladie de Crohn (MC) nous échappe toujours, mais l'importance d'une prédisposition génétique a été clairement établie par des données épidémiologiques tirées d'études menées auprès de familles et de jumeaux. Les études ont identifié deux loci de prédisposition à la maladie inflammatoire de l'intestin (MII) sur les chromosomes 12 et 16. Fait à noter, ces liens ont pu être reproduits par des chercheurs indépendants et des études se poursuivent comportant des stratégies de cartographie précise. Les régions soupçonnées sur des chromosomes 1, 3, 4, 6, 7, 10, 22 et X ont été signalées dans certaine études. D'autres gènes candidats importants qui ont fait l'objet de recherches sont l'antagoniste du récepteur de l'interleukine I, le MUC3 et les gènes du système HLA. Les données apparemment conflictuelles provenant d'études différentes d'un peu partout dans le monde pourraient s'expliquer par des distinctions d'ordre ethnique, la répartition des cas et l'hétérogénéité génétique. La réplication des associations de classe II-HLA sont HLA DRBI*0103 et DR2 (DRBI*1502), alliées à une prédisposition à la CU et HLA DRBI*03 et DR4 comme allèles de la résistance pour la MC et la CU respectivement.

Des études animales ont porté sur les mutations ciblées et sur l'analyse quantitative du locus de ce trait génétique. Les objectifs de recherches qui se poursuivent incluent une plus grand précision des liens et de l'analyse des gènes candidats et l'application éventuelle de nouvelles méthodes portant sur les polymorphismes nucléotides simples. Des progrès réalisés dans la génétique des MII pourraient fournir des renseignements plus précis sur la pathogenèse de la maladie au niveau moléculaire, ce qui se répercuterait favorablement sur la pratique clinique.
$\mathrm{T}$ he pathogenesis of ulcerative colitis (UC) and Crohn's disease (CD) is unknown, but epidemiological studies show clear evidence of genetic susceptibility. Recently, this evidence has been supplemented by strong molecular genetic data from candidate gene studies and genome-wide linkage scans. Two subchromosomal regions have been iden-

This mini-review was prepared from a presentation made at the World Congress of Gastroenterology, September 6 to 11, 1998, Vienna, Austria

${ }^{1}$ Wellcome Trust Centre for Human Genetics, University of Oxford, Oxford, ${ }^{2}$ Gastroenterology Unit, Radcliffe Infirmary, Oxford, and ${ }^{3}$ Oxagen

Ltd, Milton Park, Abingdon, United Kingdom

Correspondence: Dr David van Heel, Wellcome Trust Centre for Human Genetics, Roosevelt Drive, Headington, Oxford OX3 7BN,

United Kingdom. Telephone +44-1865-287651, fax+44-1865-287533, e-mail vanhee@@well.ox.ac.uk

Received for publication June 16, 1999. Accepted June 23, 1999 
tified in linkage studies and replicated by independent investigators. Work is now rapidly progressing along with advances in molecular genetics, to identify and characterize these susceptibility genes. These efforts should allow better understanding of disease pathogenesis and may lead to new targeted therapies. The evidence for genetic susceptibility is reviewed, and possible directions of future genetic research in inflammatory bowel disease (IBD) are outlined.

\section{EVIDENCE FOR GENETIC SUSCEPTIBILITY TO IBD}

Genes are unequivocally shown to be involved in disease susceptibility when there is a consistent Mendelian segregation pattern or a chromosomal abnormality. Although these features have not been found in IBD, genetic susceptibility has been strongly suggested by ethnic differences in disease prevalence, familial clustering of disease, twin concordance rates and, most recently, data from molecular studies in humans and in animal models.

Ethnicity and IBD: Certain ethnic groups have a consistently higher risk of developing IBD. Ashkenazi Jews have a two- to fourfold increased risk of IBD (especially CD) compared with the 150 to 200/100,000 observed in Northern Europe (1-10). The risk of developing IBD is lower in Sephardic and Oriental Jews than in Ashkenazim. The lowest overall prevalence is reported in Afro-Caribbeans $(11,12)$. The contribution of genetic susceptibility rather than entirely environmental factors to these ethnic differences is further suggested by the persistently high risk in Ashkenazi Jews regardless of their worldwide location (13). However, the relative importance of genetic and environmental influences is difficult to establish from these data (see also 'twin studies').

Familial clustering: A positive family history of IBD is found in $13 \%$ to $36 \%$ of patients (14-19). The highest prevalence of family history in IBD is found in early onset cases. The Cleveland Clinic (a tertiary referral centre) reported a 29\% family history for IBD in UC patients and 35\% in CD patients when the disease was diagnosed before the age of 21 years. More than half of the affected relatives were first degree relatives (parents, children or siblings) (16). This study is complemented by data from Johns Hopkins, where a $30 \%$ prevalence of family history was found in CD patients younger than 20 years of age at diagnosis, double that of those over 20 years of age (20). Conversely, patients with a positive family history tend to be younger at the time of diagnosis than sporadic cases $(14,21)$. Patients with early onset symptoms may be a group for whom there is a higher genetic contribution to disease risk.

Familial clustering can be measured by lambda s $(\mathrm{s})$, the ratio of risk to siblings compared with the general population risk. Measures in IBD, including two recent studies from the United Kingdom, suggest that ${ }_{s}$ for $C D$ is 15 to 35, and for $\mathrm{UC}$ is 7 to $12(19,22-24)$. By way of comparison, $s$ is less than 3 for hypertension, 15 for type 1 diabetes and 450 for a monogenic condition such as cystic fibrosis. The level of familial relative risk is related to the ease of mapping suscepti- bility loci (25). A comparatively high s in IBD compared with that in other complex diseases may explain why it has been possible to replicate IBD susceptibility loci.

Clinical patterns of familial IBD: Consecutive CD patients were enrolled in a recent study of 554 individuals at Johns Hopkins University. Seventeen per cent had a relative affected with CD (12\% for first degree relatives) and 5\% had a relative affected with UC. Eighty-six per cent of families were concordant in at least two members for disease site and $82 \%$ of the 60 families analyzed were concordant for clinical type (classified as inflammatory, stricturing or fistulizing). These authors also reported that 18 of 22 monozygotic twins with $\mathrm{CD}$ reported in the literature were concordant for disease site (26). In Oxford, affected IBD sibling pairs were concordant for disease type in $82 \%$, disease extent in $76 \%$ and extraintestinal manifestations in $84 \%$ (27). Concordance for CD location and type has also been shown by other centres (24) and increases with the number of relatives affected within the family (21). Investigators from St Marks Hospital showed that families with three or more affected first degree relatives were concordant for CD or UC status (28). These studies suggest that multiply-affected families segregate a specific clinical phenotype of IBD, rather than being at an overall increased risk of all types of IBD.

A younger age of onset in the affected offspring than in the affected parent was seen in a study of 54 IBD families (27). Other investigators (29) have shown that the younger member of second-generation first degree relative CD pairs also had disease onset at an earlier age. The tendency for successive generations to develop more severe and earlier onset disease, genetic anticipation, has been shown in some monogenic diseases. Although these data might provide preliminary evidence for genetic anticipation in $C D$, it is an unlikely explanation. The effect may be due to bias from length of follow-up, earlier diagnosis in the offspring of an affected parent or perhaps the inheritance of a greater genetic load (28).

Twin studies: Twin studies have been widely used in human genetics to study the relative contributions of genes and environment. Di- and monozygotic twins share half and nearly all their genes, respectively (excepting mitochondrial DNA and antibody/ $\mathrm{T}$ cell receptor repertoire). Unless separated at birth, they also share to a large extent the same environment, which is, therefore, controlled in epidemiological studies. In a Swedish study (30), 80 same-sex twin pairs (in whom at least one individual had IBD) were studied. In the UC group, one of 18 monozygotic and none of 20 dizygotic or unknown zygosity twins were concordant, with eight of 18 monozygotic and one of 26 dizygotic twins concordant for CD. Similar data were found in the British twin study (31), which identified twins from the national patient support group, and a Danish study (32), which used a national twin register. Combining these data gave overall UC mono- and dizygotic concordance rates of $7 \%$ and $2 \%$, respectively, compared with rates of $33 \%$ and $4 \%$ for $\mathrm{CD}$. The higher degree of heritability for CD than UC is consistent with the family study data. In addition, the scarcity of reports of 
mixed $\mathrm{CD} / \mathrm{UC}$ monozygotic twins fits with the high intrafamilial disease concordance (33).

Models of disease inheritance: Many studies have been carried out of models of inheritance of IBD. Complex segregation analysis has been used and has found evidence for a major dominant or additive disease gene in $10 \%$ of UC families $(34,35)$. Both of these studies suggested that the sporadic model was very unlikely. Studies in CD have suggested that between $7 \%$ and $30 \%$ of patients may be homozygous for a recessive disease gene (although this may also be explained by a multifactorial model) $(35,36)$. Multiple genes acting independently have also been proposed (37).

Although good evidence exists for concordance of disease type within families, CD and UC do occur within the same family. This is most strikingly shown by the presence of mixed CD and UC sibling pairs in linkage studies $(38,39)$. Thus CD and UC might be a group of oligogenic diseases sharing some susceptibility genes but differing at others (Figure 1). Several disease genes would act together to produce a genotype-dependent susceptibility risk. A positive family history confers a greater risk than smoking, diet, measles exposure or other environmental factors (40-42).

It is possible to construct a model incorporating both genetic and environmental risk factors. An environmental insult, such as a nonsteroidal anti-inflammatory drug or enteric pathogen, is the initial factor leading to impairment of the intestinal mucosal barrier. An inflammatory response is then triggered through exposure of the epithelium and lamina propria to luminal antigen. Nonsusceptible individuals then use the inflammatory response to clear antigen from the cellular compartment and repair the epithelial and mucosal defences. In susceptible individuals, impairment of the mucosal barrier, increased intestinal permeability, inappropriately increased inflammatory and immunological responses or failure to downregulate these responses may lead to chronic intestinal inflammation (43). Disruption of genes involved at any point in this pathway may lead to increased susceptibility to IBD. Understanding the complex interaction between environmental factors and genes encoding susceptibility or specific phenotype is one of the major challenges in IBD research.

\section{LINKAGE STUDIES AND SUSCEPTIBILITY LOCI}

The mode of inheritance of IBD is unknown, and classical parametric linkage analysis (using a dominant or recessive model), therefore, is unsuitable. Nonparametric methods ('model free') of linkage analysis have been developed using affected sibling or relative pairs, in order to overcome difficulties. Highly polymorphic microsatellite (simple sequence repeat) markers at average intervals of $0.4 \mathrm{cM}$ throughout the genome (44) and the development of rapid semiautomated genotyping techniques have made these studies possible. Affected families are genotyped and analyzed to identify genetic markers where the degree of allele sharing between affected individuals exceeds that expected by chance (greater than 0.5 for sibling pairs). A marker close to a disease gene is less likely to be changed by meiotic recombina-

\section{Individual}

A (Healthy)

Susceptibility genes

$\begin{array}{ll}\text { A (Healthy) } & 123456789 \\ \text { B (Total UC) } & 123456789 \\ \text { C (Small bowel CD) } & 123456789 \\ \text { D (Large bowel CD) } & 123456789 \\ \text { E (IBD, Jewish) } & 123456789 \\ \text { F (IBD, arthropathy) } & 123456789\end{array}$

Figure 1) Genetic heterogeneity in inflammatory bowel disease (IBD) A hypothetical model. Wild-type alleles are shown in normal type, mutant alleles are shaded. Phenotypic and ethnic variants of IBD are proposed to share some genes and differ at others. CD Crohn's disease; UC Ulcerative colitis

tion than one far away. If the same disease gene is involved in both affected siblings then the siblings will share the same parental allele at the nearby marker. A subchromosomal region can then be identified that is genetically linked (ie, coinherited) with an as yet unknown disease susceptibility gene or genes. To adequately cover the whole genome, a set of about 300 markers are needed ( $10 \mathrm{cM}$ intervals). Lander and Kruglyak (45) argued that, due to the statistical problems associated with the multiple tests involved, the threshold for a genome-wide screen should be one false positive in 20 genome scans ('significant linkage', maximum logarithm 10 of odds [lod] score 3.6 or higher for sibling pair studies, $\left.\mathrm{P}<2 \times 10^{-5}\right)$. Confirmation of linkage, in a new dataset, would then require $\mathrm{P}<0.01$. Suggestive linkage, likely to occur by chance once in every genome scan, would be defined by a lod score of 2.2 or greater for sibling pair studies, $\mathrm{P}<7 \times 10^{-4}$ ). These criteria are conservative and may miss weaker effects, but the cautionary tale from early studies in psychiatric genetics (many nonreplicable linkage findings using weaker significance levels) must be remembered.

Two main susceptibility loci for IBD have been identified and replicated by several independent groups. These are on chromosome 16 (pericentromeric) and chromosome 12q13-14 (Table 1).

Initial reports of strongest linkage on chromosomes 12 and 16: The first genome screen using affected sibling pair methods was in CD patients, albeit with only 25 families (40 sibling pair equivalents) (46). This is a small number of families for a complex disease with genetic heterogeneity and is likely 
TABLE 1

Linkage studies in inflammatory bowel disease (IBD)

\begin{tabular}{|c|c|c|c|c|c|c|}
\hline Published study & Study design & Study size & Phenotype & Ethnicity & $\begin{array}{l}\text { IBD1, chromosome } \\
16 \text { (maximum lod) }\end{array}$ & $\begin{array}{l}\text { IBD2, chromosome } \\
\text { 12q (maximum lod) }\end{array}$ \\
\hline $\begin{array}{l}\text { Hugot et al (46) and } \\
\text { Lesage et al (47) }\end{array}$ & Genome wide & 112 asp equivalents & CD only & European, white & $\begin{array}{l}3.17(\mathrm{CD}, \mathrm{D} 16 \mathrm{~S} 409 \\
\text { to } \mathrm{D} 16 \mathrm{~S} 419)^{*}\end{array}$ & Negative \\
\hline $\begin{array}{l}\text { Satsangi et al (38) and } \\
\text { Parkes et al (143) }\end{array}$ & Genome wide & 186 asp & $\begin{array}{c}81 \text { asp CD, } 64 \text { asp } \\
\text { UC }\end{array}$ & European, white & $\begin{array}{c}2.6 \text { (singlepoint, CD, } \\
\text { D16S411) }\end{array}$ & $\begin{array}{l}5.47 \text { (singlepoint, } \\
\text { IBD, D12S83)** }\end{array}$ \\
\hline $\begin{array}{l}\text { Ohmen et al (49), } \\
\text { Yang et al (50) }\end{array}$ & $\begin{array}{l}\text { Replication: } \\
1,3,7,12,16\end{array}$ & 117 asp & $\begin{array}{c}75 \text { asp CD, } 23 \text { asp } \\
\text { UC }\end{array}$ & $\begin{array}{l}\text { North American, } \\
33 \% \text { Jewish }\end{array}$ & $\begin{array}{l}2.41 \text { (Non-jewish } \\
\text { CD, D16S411) }\end{array}$ & $\begin{array}{c}\mathrm{NPL}=1.9(\mathrm{CD} \text { only, } \\
\text { not specified })\end{array}$ \\
\hline Mirza et al (53) & Replication: 1,16 & 70 kindreds & $\begin{array}{l}32 \text { kindreds UC } \\
\text { only, rest mixed IBD }\end{array}$ & $\begin{array}{l}\text { Mostly Northern } \\
\text { Europe }\end{array}$ & $\begin{array}{l}2.02 \text { (UC only, } \\
\text { D16S3120) }\end{array}$ & \\
\hline Duerr et al (54) & Replication: 12 & 208 arp & $\begin{array}{c}80 \operatorname{arp~CD,} 22 \text { arp } \\
\text { UC }\end{array}$ & $\begin{array}{l}\text { European Caucasoid } \\
\text { descent, } 22 \% \text { Jewish }\end{array}$ & & $\begin{array}{l}2.79 \text { (IBD, } \\
\text { D12S1724 to } \\
\text { D12S90) }\end{array}$ \\
\hline Vermeire et al (59) & $\begin{array}{c}\text { Replication: } \\
3,7,12,16\end{array}$ & 79 asp & CD mainly & Belgian, white & Negative & Negative \\
\hline Akolkar et al (57) & Replication: 12,16 & $68 \operatorname{arp}$ & CD only & Most Jewish & 0.9 & 2.08 \\
\hline $\begin{array}{l}\text { Hampe et al (39) and } \\
\text { Curran et al (134) }\end{array}$ & Genome wide & 353 asp & $\begin{array}{c}162 \text { asp CD, } 114 \text { asp } \\
\text { UC }\end{array}$ & $\begin{array}{l}\text { White Northern } \\
\text { European }\end{array}$ & $\begin{array}{l}1.71 \text { (CD only, } \\
\text { D16S407) }\end{array}$ & $\begin{array}{l}1.82 \text { (CD only, } \\
\text { D12599) }\end{array}$ \\
\hline
\end{tabular}

*Initial genome screen microsatellite markers for a putative susceptibility locus, meeting criteria for significant linkage (reference 45). Other suggestive linked loci are shown where the criteria for suggestive linkage are met (see text). ${ }^{\prime}$ Confirmatory studies for a locus where $P<0.01$, or described as negative if $P>0.05$. Multipoint logarithm of odds (lod) scores are given where possible. arp affected relative pairs; asp affected sibling pair; CD Crohn's disease; UC UIcerative colitis; NPL Nonparametric linkage score

to give type II errors. Three markers on chromosome 16 and one on chromosome 1 had an increased allele sharing among the sibling pairs $(\mathrm{P}<0.01)$. The chromosome 16 linkage was confirmed in a second panel of 53 families (70 sibling pair equivalents), but the chromosome 1 linkage was not replicated. Although the $\mathrm{P}$ value of $1.5 \times 10^{-5}$ does not strictly meet Lander's criteria, the two-stage design of the study found $\mathrm{P}<0.01$ in both data sets and excluded other regions of linkage. The chromosome 12 linkage has not been replicated in this CD family panel (47).

The Oxford group carried out the first genome-wide search in both CD and UC in 186 affected British white sibling pairs from 160 families (38). The much larger panel of sibling pairs used in this study had greater power to detect regions of linkage. The strongest linkage was found for chromosome 12, with five markers spanning $41 \mathrm{cM}$ around the microsatellite marker D12S83, showing distortion of allele sharing. The chromosome 12 locus has now been fine mapped with a set of 37 markers, and a positive association found (by the transmission disequilibrium test) for a threemarker haplotype within $0.5 \mathrm{cM}$ of D12S83 (48). Linkage was confirmed for chromosome 16 in the CD subgroup only, with a marker lying between the two most strongly linked markers used in the earlier study. A region was identified on chromosome 7q22, again with four flanking markers, spanning $54 \mathrm{cM}$ and meeting 'suggestive' criteria for linkage. Two markers within $6 \mathrm{cM}$ on chromosome $3 \mathrm{p} 21$ also met the 'suggestive' linkage criteria.

Replication of these linkages and more recent genome scans: The chromosome 16 region was analyzed and the linkage replicated in American families in a study from Los Angeles, California (49). In this study, the locus appeared to be involved only in non-Jewish CD patients and not in the one-third of the sibling pair panel of Ashkenazi Jewish origin. The UC patients studied showed no linkage to chromosome 16, although again the power was less in the far smaller UC subgroup. These authors replicated the chromosome 12 locus in $\mathrm{CD}$, but not $\mathrm{UC}$ sibpairs (50). A positive transmission disequilibrium test was obtained at D12S85 (personal communication). No linkage was seen for chromosomes 3 and 7. An Australian study confirmed the chromosome 16 locus in 54 Australian CD families, with the highest lod score to date for this locus (51). Importantly, the sibpairs used all had available DNA from both parents to confirm allelic identity by descent. Mis-specification of allele frequencies may occur when parents are not available (52). Using haplotype evaluation of recombination events, the authors were able to narrow the chromosome 16 region down to $1.7 \mathrm{cM}$. Transmission disequilibrium testing, however, failed to detect any association within this region. Possible explanations for this include the observation of multiple disease haplotypes within one large pedigree - indicating genetic 
heterogeneity or that the size of the region may still be too great for detection by association study with infrequently spaced markers. A further study in Northern European patients ( 32 kindreds with UC only, and 38 mixed IBD kindreds) at the chromosome 16 locus reported linkage in the UC group only (53). However the P value of 0.02 obtained with D16S3120 does not quite meet the strict criteria for replication, and again the UC group was small.

Investigators from Pittsburgh (54) have also confirmed linkage to the chromosome 12 region in $127 \mathrm{CD}$ - and 122 UC-affected relative pairs. Both CD and UC pairs contribute equally. The linkage method of 'affected relative pair analysis' used has more power when a trait allele is rare and less power when a trait allele is common compared with affected sibling pair analysis (55). The transmission disequilibrium test was positive at $\mathrm{D} 12 \mathrm{~S} 83$, but this result was not significant after statistical correction for the multiple comparisons made. These investigators have more recently published data replicating the region on chromosome 7 found initially in the Oxford genome scan (56).

Three further studies aimed at replicating the previously reported regions of linkage show differing results. A study from New York has also replicated the chromosome 12 locus in predominantly Jewish CD sibpairs (57). Canadian patients (114 CD and 36 UC sibling pairs) from 161 Toronto kindreds showed no linkage to the chromosome 12 or 16 loci or the initial Oxford chromosome 3 and 7 regions (58). These loci have also not been replicated in $76 \mathrm{CD}$ sibpairs from 91 Belgian white families (59). One explanation for these apparently conflicting results is the ethnic and case mix in the groups studied. Genetic heterogeneity, where nonoverlapping sets of gene mutations all result in intestinal inflammation (Figure 1), is likely to be a further factor.

The third genome-wide screen in 174 American families with $175 \mathrm{CD}$-affected relative pairs and $26 \mathrm{UC}$ relative pairs was performed in Chicago (60). Over one-third of families were of Ashkenazi Jewish descent. A denser set of 377 microsatellite markers allowed examination of regions not well covered in previous screens. Three novel susceptibility loci were identified - at chromosome $3 \mathrm{q}$ with a broad region of linkage in all families, at chromosome $1 \mathrm{p}$ with linkage in non-Ashkenazi families and at chromosome $4 \mathrm{q}$ with greatest linkage in the mixed $\mathrm{CD}$ and $\mathrm{UC}$ subset of families. The chromosome 16 linkage was replicated, with greatest linkage again in CD families and no linkage in UC families. This linkage proved greatest in the Askenazim. An epistatic interaction was observed between the chromosome 1 and 16 loci. No confirmation was provided for the chromosome $3 \mathrm{p}$, 7 or 12 loci identified by the Oxford genome scan, although again the number of UC studied was much smaller than for $\mathrm{CD}$. Interestingly, these investigators have found pedigrees in which an individual has a young age of onset of disease to demonstrate greater linkage to their chromosome $1 p, 3 q$ and the replicated chromosome 16 loci (61). This observation fits well with the family study data suggesting a greater genetic component to IBD susceptibility for this group.

In the most recent, and fourth genome-wide analysis in
IBD, 162 CD- and 114 UC-affected sibling pairs were genotyped from 268 white northern European families (39). The chromosome 16 linkage was replicated for CD only, and the chromosome 12 locus was replicated in CD and IBD overall, but did not quite reach the significance criteria for sibling pairs with UC only. The two loci were predicted to be additive in effect rather than interact epistatically. The chromosome 4 linkage reported previously was confirmed (60). Novel susceptibility loci were reported on chromosomes 1, 6, 10, 22 and X, although again these did not meet Lander's strict criteria for first genome scan data. The chromosome 1 locus found is $100 \mathrm{cM}$ q telomeric to the previous reported chromosome 1 locus, and thus does not overlap (60). Linkage to the HLA region was shown in this study (see below). Interestingly, given the association between Turner's syndrome and IBD (62-67), linkage to the X chromosome has been reported. The Belgian group have also found linkage to the $\mathrm{X}$ chromosome (68).

In summary, strong evidence for linkage exists for chromosomes 12 and 16 (Table 1). The chromosome 16 linkage has been demonstrated by six independent groups and appears to be most strongly linked to CD. Evidence for linkage to chromosome 12 has been provided by five groups. Chromosome 12 appears to be linked to both CD and UC. The limited number of UC sibling pairs in many of the studies may mean that sufficient power was not present to detect linkage to chromosome 12 , although alternative explanations include ethnic and case mix differences and genetic heterogeneity. Several other putative susceptibility loci have been identified, but these await wider replication.

\section{METHODS UNDERLYING CANDIDATE GENE ASSOCIATION STUDIES}

Many new polymorphisms have been described in genes involved in the immune and inflammatory response over the past decade, and several candidates have been studied in IBD patients. Genes outside as well as within the replicated regions of linkage have been suggested from studies of expression pattern, function or animal models. Association studies are more powerful tools than linkage analysis in these studies, and because linkage disequilibrium operates over $1 \mathrm{cM}$ at most, a positive association with a gene or marker may define the true susceptibility gene $(69,70)$.

Case-control association studies compare allele frequencies in affected patients with that in a set of matched controls. Spurious associations can occur due to population stratification - where the study and control groups are drawn from genetically distinct subpopulations and unrecognized ethnic differences in allele and/or disease frequencies exist. Incorrect matching of cases and controls may also occur. To avoid these problems, family-based studies have been designed using genotypes from an affected individual and two parents. This allows the nontransmitted parental alleles to be used as internal well matched controls. One such method, the transmission disequilibrium test (TDT), has been widely used in complex genetics $(71,72)$ but so far in only two studies in IBD. Future studies in IBD are likely to use the TDT 
TABLE 2

Positional candidate genes for inflammatory bowel disease (IBD) on chromosomes 12 and 16

\begin{tabular}{|c|c|c|c|}
\hline Chromosome & Gene & Name & Possible role in IBD \\
\hline 12 & STAT6 & $\begin{array}{c}\text { Interleukin } 4 \\
\text { transcription factor }\end{array}$ & $\begin{array}{c}\text { Regulation of Th1/Th2 } \\
\text { cells }\end{array}$ \\
\hline 12 & ITGA5 & Alpha 5 integrin & Cell adhesion \\
\hline 12 & ITGB7 & Beta 7 integrin & Leucocyte adhesion \\
\hline 12 & MMP18 & $\begin{array}{c}\text { Matrix } \\
\text { metalloproteinase }\end{array}$ & $\begin{array}{l}\text { Degrades extracellular } \\
\text { matrix }\end{array}$ \\
\hline 12 & IFNG & Interferon gamma & Th1 pathway \\
\hline 12 & NRAMP2 & $\begin{array}{c}\text { Natural resistance } \\
\text { associated } \\
\text { macrophage protein } 2\end{array}$ & $\begin{array}{l}\text { Intestinal iron } \\
\text { transport }\end{array}$ \\
\hline 16 & ITGAX & $\begin{array}{l}\text { Leucocyte surface } \\
\text { antigen (alpha-X } \\
\text { integrin) }\end{array}$ & Leucocyte adhesion \\
\hline 16 & $I L 4 R$ & Interleukin 4 receptor & $\begin{array}{c}\text { Inflammatory cell } \\
\text { regulation }\end{array}$ \\
\hline 16 & $S P N$ & Sialophorin & $\mathrm{T}$ cell activation \\
\hline 16 & CD19 & $\begin{array}{l}\text { B lymphocyte antigen } \\
\text { CD19 }\end{array}$ & $\begin{array}{l}\text { B lymphocyte } \\
\text { function }\end{array}$ \\
\hline
\end{tabular}

Th T helper

more widely as families are collected due to its power and robust nature.

A further problem of association studies is that there may well be no association to find, and so each test performed carries an independent risk of a false positive result (69). A Bonferroni correction has to be applied, and unfortunately $\mathrm{P}$ values are often still presented uncorrected. The best test of an association is replication by different investigators in a separate patient group.

\section{POSITIONAL CANDIDATE GENES FOR THE WIDELY REPLICATED CHROMOSOME 12 AND 16 SUSCEPTIBILITY LOCI}

Identification of genes within a region of linkage (positional candidates) has been made simpler by the publication of a physical map containing transcript markers for nearly half of all predicted human disease genes (73). Sequence tagged sites have been taken from cDNA sequences and ordered by radiation hybrid mapping, along with a framework of microsatellite markers. The accompanying website provides the map position information along with data on known gene function and homologies with other species (74). Promising positional candidates identified in this way for chromosomes 12 and 16 are shown in Table 2.

Interferon-gamma (IFN) (chromosome 12q14) is a key Thelper (Th)- 1 cytokine, and abnormalities of this pathway are well described in animal models and in humans with IBD. An intragenic microsatellite marker was typed in 506 simplex families (ie, patients and parents) and 133 affected relative pairs. A nonsignificant lod score of 0.67 was obtained for $\mathrm{CD}$, although this sample was less than the 353 sibling pairs used by these authors in their recent genome scan replicating the chromosome 12 linkage. The transmis- sion disequilibrium test was negative for $\mathrm{CD}, \mathrm{UC}$ and IBD overall (75). The genomic sequence of IFN is only $6 \mathrm{~Kb}$, and any mutation is highly likely to be in linkage disequilibrium with the polymorphic intragenic repeat. The authors propose that abnormalities related to IFN observed in IBD are likely to be a secondary phenomenon.

Data have been reported in abstract form for two other candidates on chromosome 12 . Vitamin D has multiple immune actions, including the suppression of lymphocyte proliferation and inhibition of cytokine production. The Taq1 t allele and tt genotype of the vitamin D receptor gene (chromosome 12q13) were significantly associated with CD (76). This genotype has been reported to be of functional importance in several infectious diseases. Natural resistanceassociated macrophage protein (NRAMP)2 (chromosome 12q13) is involved in intestinal iron transport and has homology to NRAMP1 (discussed earlier). Three restriction fragment length polymorphisms were assessed, and the gene excluded as a candidate by linkage and TDT analysis. No novel mutations were found by direct sequencing of the gene in $33 \mathrm{CD}$ patients (77).

Positional candidates on chromosome 16 include the CD19 gene and CD43 (sialophorin) gene, involved in B lymphocyte function and intracellular adhesion molecule-1 (ICAM-1) interactions, respectively. Direct sequencing of the coding sequence, including intron-exon junctions, was carried out in $10 \mathrm{CD}$ patients and two healthy controls. Two single nucleotide polymorphisms were identified in each gene, three of which were silent mutations and one a single base amino acid missense mutation in CD19 exon 3. The TDT was negative for the CD19 missense mutation in 78 $\mathrm{CD}$ families. Although rare alleles may have been missed, the CD19 and CD43 genes did not appear to be involved in the genetic predisposition to $\mathrm{CD}$ in these families (78).

\section{HUMAN LEUKOCYTE ANTIGEN TYPE AND IBD}

Among the first candidate genes to be studied in IBD were those of the human leukocyte antigen (HLA) system, involved in antigen processing and presentation. HLA class II molecules present partially digested antigen to the $T$ cell receptor and play a central role in the immune response. HLA-DP, -DQ and -DR code for the alpha and beta chains of the class II molecule. HLA-DP and -DQ genes are polymorphic for both chains. HLA-DR is only polymorphic for the beta chain, and the beta1 chain is the most polymorphic of all. Initial studies based on serology were superseded by the increased number of polymorphisms detectable by DNA-based genotyping. The most consistent results have been seen in Japan, where the most genetically homogenous population is found. Conflicting results may be explained by genetic heterogeneity, small sample sizes, the lack of statistical correction for multiple testing and the limited number of HLA polymorphisms examined in some studies as well as by ethnic differences between populations.

UC: HLA-DRB1 and -DQB have been studied in white patients, with linkage and haplotype sharing observed in 29 affected UC sibling pairs (but not in CD sibling pairs) (79). 
Allelic association was observed with the rare DRB1*103 allele (8.3\% UC versus $2.1 \%$ controls) and DRB1*12. The DRB1*0301 DQB*0201 (DR3 DQ2) haplotype was reduced in females, particularly in those with distal UC. This haplotype was also predictive of extensive UC in both sexes in the 175 UC patients studied. HLA linkage had not been confirmed in other earlier studies $(80,81)$. In the much larger genome-wide scans in affected sibling pairs, only one study found significant linkage with IBD to the HLA region (39). However, a nonsignificant distortion toward allele sharing in UC was observed for the same marker (D6S276) in the Oxford genome scan (38). In contrast to affected sibling pair linkage methods, allelic association studies have more power to detect small effects once the precise region of interest has been identified (70). The increased frequency of the rare DRB1*0103 allele has been confirmed, again in extensive $\mathrm{UC}$ and also in patients undergoing colectomy (82). The more common DRB1*15 was also increased in these $98 \mathrm{UC}$ patients investigated. DRB1*0103 was present in $14.1 \%$ of UC patients undergoing colectomy and ileoanal pouch anastomosis versus $3.2 \%$ in controls, and was shown to be predictive of extensive disease and extraintestinal manifestations in a separate series from Oxford (83). UC patients in California had a statistically significant positive association with the HLA-DR2 allele (84), but this has not been shown in several other studies in white patients $(85,86)$. Many of these conflicting studies have relied on serological rather than molecular methods (87-91).

Japanese UC patients also have an increased frequency of DR2 (92,93-95). The molecularly defined DRB1*1502 allele of serological DR2 was present in $49.2 \%$ of $59 \mathrm{UC}$ patients versus $17.6 \%$ in controls, and this genotype carried an increased need for steroid treatment (93). The DRB1*1502 association has also been observed in patients from Turkey (96). However, this allele is rare in non-Jewish European whites (5\% versus $57 \%$ in Japan). Thus, HLA class II associations with UC clearly differ between populations and emphasize the necessity to define ethnicity when studying populations.

CD: Californian CD families have shown increased haplotype sharing in multiplex families (97). However, other studies that have found evidence for linkage of IBD to the HLA locus have found the effect to be greater for $\operatorname{UC}(38,39)$. One of the largest association studies of 344 white $C D$ patients found a negative association with DRB $1 * 03$ (6.5\% CD versus $13.8 \%$ controls) and increased DRB1*01,07 (98). The finding that DRB1*03 may be a resistance allele and the positive association with DRB1*07 have been replicated (99). The DRB3*0301/DRB1*1302 haplotype has also been associated with CD in white patients (100-102). A marked decrease in DRB1*03 was found in fistulizing CD (103). A positive DQB1*0501 association with CD has been found in two studies $(84,98)$. Japanese studies have reported associations with DQB1*04 and DQA1*0102 as a resistance allele (104). However, other studies in CD have found no or conflicting disease associations.

Arthropathy: The peripheral arthropathy associated with
IBD has been divided into pauciarticular large joint and bilateral symmetrical types (105). Molecular genetic studies of HLA in these patients have provided preliminary evidence for genes controlling IBD arthropathy. DR103 is significantly increased in IBD patients, with large joint type 1 arthropathy being found in 40\% versus 3\% controls (106). Associations with class I HLA-B27 and B35 were also noted for type I arthropathy. In contrast, B44 was increased in the small joint type 2 IBD arthropathy.

The major histocompatibility complex (MHC) plays a relatively minor role in IBD compared with that in autoimmune disease such as celiac disease and insulin-dependent diabetes, confirmed by the weak evidence for linkage compared to other susceptibility loci (see below). Replicated positive associations have been obtained with HLA DRB1*0103 in whites with extensive UC and DR2 (DRB1*1502) in Japanese UC patients. DRB1*03 is replicated as a resistance allele in white CD patients, and DR4 protects against UC. A recent meta-analysis of 27 class II HLA studies confirmed these findings (107). HLA associations are more consistently implicated in UC than CD. HLA genes may play a disease-modifying role, rather than influencing IBD susceptibility per se, as shown by the association studies analyzing disease extent, character and arthropathy. These associations may reflect direct $T$ cell responses to class II presented peptides, a T cell-driven autoimmune effect triggered by an initial pathogen or even linkage disequilibrium between the HLA allele and a functional gene nearby.

\section{OTHER CANDIDATE GENES}

Many other genes have been studied in IBD on the basis of potential function alone. The interleukin (IL)-1 receptor antagonist (IL-1RA) (chromosome 2q) is a potent antiinflammatory protein, implicated in intestinal inflammation from animal studies. An initial case-control study in UC and $\mathrm{CD}$ found an association in UC patients with allele 2 of an intragenic variable number of tandem repeats (VNTR) (35\% versus $24 \%$ controls) (108). In the Oxford study (109), no significant differences among CD patients, UC patients and controls were initially seen. Analysis of subgroups in UC showed allele 2 to be increased in antineutrophil cytoplasmic antibody (ANCA)-positive UC patients, and more frequent in extensive disease than distal colitis (83). IL-1 and receptor antagonist genes were not associated with UC overall in a Dutch study, but allele 2 of IL-1RA was increased in extensive disease (82). This did not retain significance after correction for multiple comparisons. The IL-1 and IL-1RA genes are in linkage disequilibrium, and while no association with UC overall has been shown by some groups (110), dissection of the interplay between genes of the IL-1 system has found positive associations (111). Studies of key cytokine genes involved in inflammation must also be able to explain the intestinal specificity of inflammation (or the lack of inflammation in other tissues) because it is possible that some abnormalities observed in cytokine levels are a secondary rather than an initiating step.

ICAM-1 (chromosome 19p13) is involved in neutrophil 
adhesion, and two exonic polymorphisms have been tested in UC and CD patients. No association was found for $C D$ or UC overall. After stratification by ANCA status, ANCApositive $\mathrm{CD}$ and ANCA-negative UC had an increased frequency of allele R241 (112). Codon 241 is in a functionally important domain of ICAM-1, and this interesting association awaits replication by other groups. NRAMP1 (chromosome $2 \mathrm{q} 35$ ), involved in macrophage regulation, has been implicated in susceptibility to tuberculosis and other infections (113). Two close polymorphic microsatellite markers were examined for associations in CD and UC patients. Two haplotypes found in $\mathrm{CD}$ patients were significantly different from controls (114). Again this merits replication and screening of the gene for possible mutations. Beta1 and beta2 kinin receptor genes (chromosome 14q32) have also been studied by one group because of evidence for kinin-mediated gastrointestinal inflammation (115). A polymorphism in the beta1 receptor promoter region was significantly different between IBD patients and healthy controls. This too awaits confirmatory studies by others.

The gene encoding tumour necrosis factor alpha (TNF ) (chromosome 6p21) has been studied because of well described alterations of TNF production in IBD, and because of the efficacy of anti-TNF monoclonal antibodies in CD (116). Many TNF polymorphisms have been described, of which the -308 and -238 promoter mutations have been suggested to be functional (117). As for the IL-1RA polymorphisms, data from several published studies and analyses of subgroups have been discordant $(108,109,118)$. Investigators in Los Angeles, California found a TNF microsatellite haplotype (a2b1c2d4e1) in 24\% of CD patients versus $7 \%$ of controls, although a French group did not $(119,120)$. This haplotype is in linkage disequilibrium with HLA-DR and $D Q$ alleles, and dissection of the pathological mutation (versus polymorphism) in this region of chromosome 6 is needed. Of interest, linkage of $\mathrm{CD}$ to the $\mathrm{MHC}$ region has also been reported by these Californian investigators. Interestingly, one study (103) has reported a low frequency of HLADRB1*03 and a normal frequency of TNF -308 in a subgroup of CD patients with perianal fistulas. Recombination events in this subgroup of patients were proposed by the authors to play a role.

TAP1 and TAP2 genes (chromosome 6p21) are involved in the transfer of antigenic peptides before their association with class I HLA molecules. No difference in TAP1 and TAP2 alleles was found among UC patients, CD patients and controls (121). A significant (corrected) decrease in TAP2 AA allele frequency was found in CD patients who did not respond to steroid therapy. MHC class I-like gene-A (MIC-A) is an atypical MHC class I molecule, found in the same genomic region, expressed on the intestinal epithelial surface. It is thought to interact with gamma-delta $\mathrm{T}$ cells and be upregulated by cellular stress. MIC-A allele*007 was significantly associated with UC compared with controls ( $32 \%$ versus $11 \%$ ), and this was confirmed in a second independent cohort by these investigators (122).

Chemokines are released by intestinal epithelium, play- ing a major role in recruitment and activation of inflammatory cells. The chemokine receptor CCR-5 (chromosome $3 \mathrm{p} 21$ ) has a 32 base pair deletion found to confer resistance to human immunodeficiency virus, and is close to a linked marker D3S1573 (38). Forty-four per cent of CD patients and $31 \%$ of UC patients versus $13 \%$ of controls possessed this functional deletion (123).

Abnormalities of intestinal mucin expression have been observed in IBD patients and the cotton-top tamarin model of colitis. The MUC3 gene (chromosome 7q22) lies close to a microsatellite D7S669, linked to IBD with a lod score of 3.08 in the Oxford genome scan (38). Polymorphisms of VNTRs within the MUC3 gene in 75 Japanese patients with $\mathrm{UC}$ and 168 Japanese controls were analyzed. When the frequency of patients carrying one or two rare VNTR alleles was compared with that of controls, a significant increase was found in the Japanese patients (odds ratio 2.72). Similar results were found in white patients. Rare alleles of MUC3 may confer predisposition to UC, although these were found in only $22 \%$ of UC patients studied (124).

\section{GENETIC INSIGHTS FROM ANIMAL MODELS}

Lessons have been gained from spontaneous, chemicalinduced and genetically engineered animal models of IBD. Many studies have used inbred animal strains, and in these models development of intestinal inflammation is strain dependent. In the dextran sulphate sodium (DSS) model, for instance, $\mathrm{C} 3 \mathrm{H} / \mathrm{HeJBir}$ mice are highly susceptible and display spontaneous colitis, while the C57/black 6 strain is resistant (125). Similar findings apply in gene-targeted models of IBD, in addition to chemically induced colitis and are furthermore seen in rat models.

Intestinal inflammation has been observed in mice with diverse targeted gene alterations including alpha-beta $T$ cell receptor, keratin $8, \mathrm{TNF}$, transforming growth factor-beta and IL-2, -7 and -10 genes (126-130). In another model, mice with a targeted deletion of the $G$ protein $G$ i2 develop IBD resembling UC, and further develop adenocarcinoma of the colon (131). Interestingly, the human homologue of the Gai2 gene (chromosome 3p21), which encodes an inhibitory $\mathrm{G}$ protein expressed in many tissues, is located within a region of linkage identified in one IBD genome scan (38). The presence of gut bacterial flora has been shown to be a key element in the development of inflammation in animal models. IL-2 and IL-10 knockout mice develop IBD but not under germ-free conditions (132). These various genetically engineered models develop colitis predominantly via a Th1 $\mathrm{T}$ cell-mediated pathway, and less commonly via a Th2 pathway. That diverse immunological defects all lead to IBD via one of two final common pathways suggests that many candidate genes might be involved in human IBD.

A genome-wide screen for quantitative trait loci in the DSS mouse model was carried out using both susceptible and resistant strains (125). Two of the loci were further evaluated in congenic strains. Susceptibility loci were found on mouse chromosomes 2 and 5 . Reduced susceptibility was observed in congenic mice carrying alleles from chromosomes 
2 and 9 from resistant mouse strains. The authors concluded that multiple genes control susceptibility to DSS colitis in mice. Candidate genes with human homologues within the congenic chromosome 9 interval include CD3 subunit genes, IL-10 receptor and IFN -inducing factor. Candidates on mouse chromosomes 2 and 5 include cell adhesion molecules, platelet-derived growth factor A chain (acute inflammation) and proinflammatory cytokines IL-1 and -1 .

Animal models are thus proved useful in studying specific targeted gene mutations and susceptibility loci for induced disease as well as the more traditional physiological and drug treatment studies. Insights into immunological mechanisms of human IBD, as well as potential human candidate genes have been gained. Studies of gene function in animal induced mutants will follow from identification and characterization of candidate genes in human IBD.

\section{OVERVIEW AND DIRECTIONS FOR FUTURE WORK}

IBD genetics have advanced rapidly in the past five years. Earlier data were limited to epidemiological and serological HLA association studies. Molecular biological techniques have progressed through genome-wide linkage studies to widespread replication of regions of linkage and the analysis of positional candidate genes. In particular, IBD is unique among complex genetic disease in having two non-HLA susceptibility loci reproduced by several investigators using different patient sets.

The relatively small role of HLA genotypes in IBD susceptibility is becoming clearer. HLA DRB1*0103 and DR2 (DRB1*1502) are involved in UC susceptibility in white and Japanese populations, respectively, while DRB1*03 and DR4 appear to be resistance alleles for CD and UC. Studies in arthropathy and of different clinical types of IBD suggest that HLA may have a greater role in modifying IBD phenotype, than on overall disease susceptibility.

The two regions of linkage on chromosomes 12 and 16 both span over 20 million base pairs, regions that may each contain several hundred genes. Identification of susceptibility genes is thus a formidable prospect, and strategies proposed include analysis of subgroups, fine mapping, metaanalysis, and a systematic analysis of all candidates (Figure 2). Fine mapping of these loci using a dense set of microsatellite markers is being attempted, with some promising initial results (48). In contrast to simple Mendelian traits where the gene always lies within the maximal region of linkage, in complex diseases the gene may well lie outside the maximal region (133). In support of this argument, the positive studies for chromosome 12 found three peaks of linkage, each approximately $10 \mathrm{cM}$ apart. It is also possible that more than one susceptibility gene may reside within the region $(50,54,134)$. The power of linkage studies to narrow a region is limited. Indeed, over 700 sibling pairs may be needed to narrow down to $1 \mathrm{cM}$ a locus causing a twofold increased risk (135). An international IBD genetics consortium has been set up to carry out a meta-analysis of linkage data for this reason, and should report later in the year (136). Genetic het-

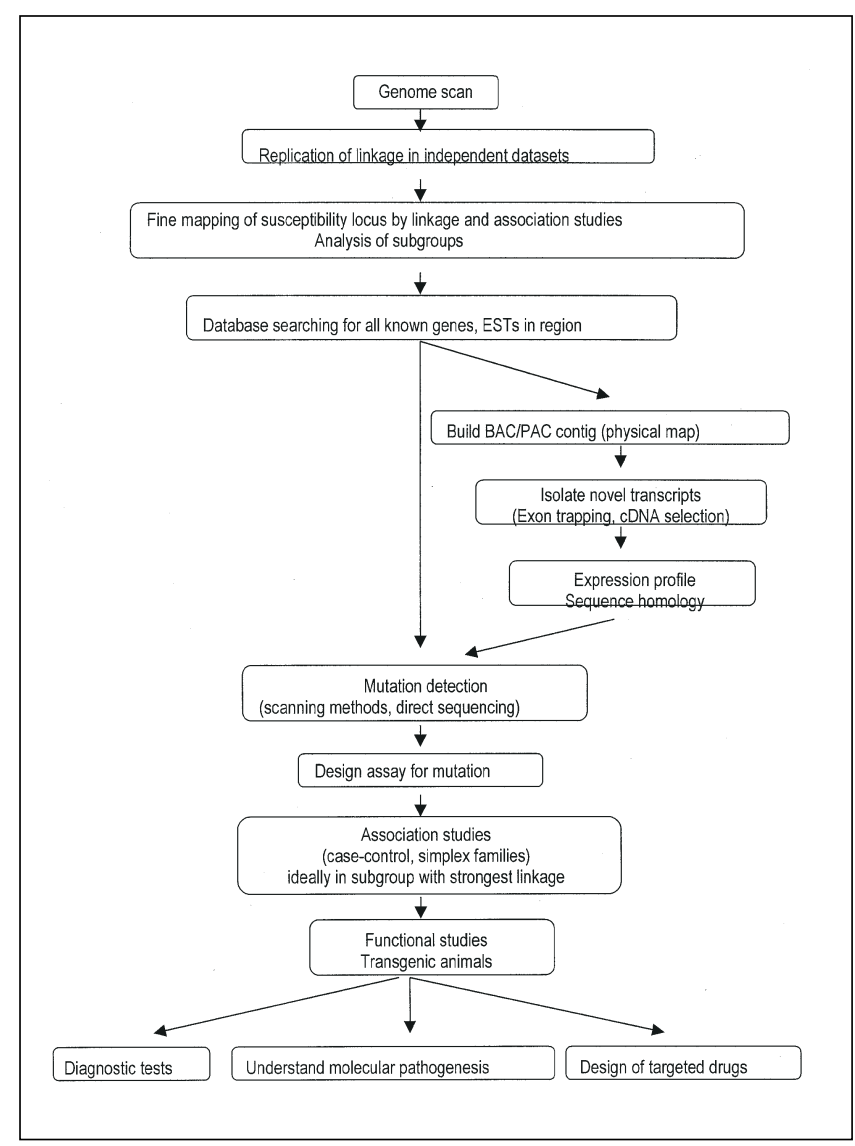

Figure 2) From linkage to gene. BACP Bacterial artificial chromosome; EST Expressed sequence tag; PAC P1 artificial chromosome

erogeneity within $\mathrm{CD}$ and UC contributes to these difficulties. Analysis of specific subgroups, eg, early age of onset or large families, may allow identification of patients with a stronger genetic susceptibility.

New developments in association studies, such as the TDT, provide more statistically robust methods of testing than the traditional case-control study. Two studies have suggested linkage disequilibrium for a microsatellite marker D12S83 on chromosome $12(48,54)$. However recent statistical modelling suggests that useful levels of linkage disequilibrium in an outbred population may extend over very small regions $(3 \mathrm{kB}$ on average, although with wide regional variation) (47). Microsatellite markers may be unable to provide sufficient resolution, being too widely spaced, and other markers such as single nucleotide polymorphisms (SNPs) may hold more promise. An alternative strategy is to identify all the potential genes within the large regions of linkage and apply methods for detection of novel mutations. The more likely candidates may be identified on the basis of known or predicted function and tissue specific expression. Systematic analysis of positional candidate genes, starting with the most plausible biological candidates, is likely to progress in parallel with attempts to narrow the regions of linkage.

Single nucleotide polymorphisms are mainly diallelic polymorphisms that occur on average every $1 \mathrm{~Kb}$ throughout the genome. Although they are less informative than microsatellites they are more frequent and mutationally more sta- 
ble, making them suitable for linkage disequilibrium studies to map disease-causing mutations (137). Genome-wide association studies using SNP are now feasible as DNA microchip technology becomes commercially available $(138,139)$. In order to facilitate these and other studies, an international SNP consortium has been set up to build up a large database of 300,000 SNPs (140). The risk of false-positives due to multiple testing will have to be overcome in SNP-based association studies, but strategies are being developed $(137,141)$. SNP association studies may thus be superior to linkage for both narrowing regions of linkage and detecting the low penetrance genetic effects thought to occur in complex disease.

Identification of a susceptibility gene and characterization of the functional significance of mutations has the potential to unravel the molecular pathogenesis of IBD. This may allow new therapeutic measures to be developed and al-

\section{REFERENCES}

1. Nordenvall B, Brostrom O, Berglund M, et al. Incidence of ulcerative colitis in Stockholm county 1955 - 1979. Scand J Gastroenterol 1985;20:783-90.

2. Garland CF, Lilienfeld AM, Mendeloff AI, Markowitz JA, Terell KB, Garland FC. Incidence rates of ulcerative colitis and Crohn's disease in fifteen areas of the United States. Gastroenterology 1981;81:1115-24.

3. Binder V, Both H, Hansen PK, Hendriksen C, Kreiner S, Torp-Pedersen $\mathrm{K}$. Incidence and prevalence of ulcerative colitis and Crohn's disease in the County of Copenhagen, 1962 -1978. Gastroenterology 1982;83:563-8

4. Evans JG, Acheson DE. An epidemiological study of ulcerative colitis and regional enteritis in the Oxford area. Gut 1965;6:311-24.

5. Morris T, Rhodes J. Incidence of ulcerative colitis in the Cardiff region 1968 -1977. Gut 1984;25:846-8.

6. Lee FI, Costello FT. Crohn's disease in Blackpool - incidence and prevalence 1968-80. Gut 1985;26:274-8.

7. Monk M, Mendeloff AI, Seigel CI, Lilienfeld A. An epidemiological study of ulcerative colitis and regional enteritis among adults in Baltimore. 1. Hospital incidence and prevalence, 1960-1963. Gastroenterology 1967;53:198-210.

8. Acheson ED. The distribution of ulcerative colitis and regional enteritis in United States veterans with particular reference to the Jewish religion. Gut 1960;1:91-3.

9. Gilat T, Grossman A, Fireman Z, Rosen P. Inflammatory bowel disease in Jews. In: McConnell R, Rozen P, Langman M, Gilat T, eds. The Genetics and Epidemiology of Inflammatory Bowel Disease. Basel: Karger, 1986:135-40.

10. Yang H, McElree C, Roth M-P, Shanahan F, Targan ST, Rotter JI. Familial empirical risks for inflammatory bowel disease: differences between Jews and non-Jews. Gut 1993;34:517-24.

11. Robinson WW, Bentlif PS, Kelsey JR. Observations on 261 consecutive patients with inflammatory bowel disease seen in the southwest United States. Dig Dis Sci 1980;25:198-204.

12. Samuels AD, Weese JL, Berman PM, Kirsner JB. An epidemiologic and demographic study of inflammatory bowel disease in black patients. Dig Dis Sci 1974;19:156-60.

13. Roth MP, Petersen GM, McElree C, Feldman E, Rotter JI. Geographic origins of Jewish patients with inflammatory bowel disease. Gastroenterology 1989;97:900-4.

14. Monsen U, Bernell O, Johansson C, Hellers G. Prevalence of inflammatory bowel disease among relatives of patients with Crohn's disease. Scand J Gastroenterol 1991;26:302-6.

15. Lashner BA, Evans AA, Kirsner JB, Hanauer SB. Prevalence and incidence of inflammatory bowel disease in family members. Gastroenterology 1986;91:1396-400.

16. Farmer RG, Michener WM, Mortimer EA. Studies of family history among patients with inflammatory bowel disease. Clin Gastroenterol 1980;9:271-7.

17. Korelitz BI. Epidemiological evidence for a hereditary component in Crohn's disease. In: Pena AS, Wterman IT, Booth CC, Strober W, eds. Recent Advances in Crohn's Disease. The Hague: Martinus Nijhoff, 1981:208-12.

18. Weterman IT, Pena AS. Familial incidence of Crohn's disease in The low investigation of potential environmental trigger factors. Clinical practice may include stratification of patients by genotype and potential response to drug therapy. For example, susceptibility to the myelosuppresive effects of azathioprine is now partly understood at the molecular level (142). Prognostication using genotype may be possible, and initial data for HLA type in IBD-associated arthropathy and HLA DR103 in prediction of need for surgery in UC are promising. Genetic counselling, both of individual patients and their relatives, may eventually become possible. Tremendous progress has been made in IBD genetics over the past five years, and there is great optimism that further advances will follow rapidly.

ACKNOWLEDGEMENTS: David van Heel is a Medical Research Council Clinical Training Fellow, and Jack Satsangi a Medical Research Council Clinician Scientist.
Netherlands and a review of the literature. Gastroenterology 1984;86:449-52.

19. McConnell RB. Genetics of inflammatory bowel disease. In: Allan RN, Keighley MRB, Alexander-Williams J, Hawkins C, eds. Inflammatory Bowel Disease. Edinburgh: Churchill Livingstone, 1990:11-23.

20. Polito JM, Childs B, Mellits D, Tokayer AZ, Harris ML, Bayless TM. Crohn's disease: influence of age at diagnosis on site and clinical type of disease. Gastroenterology 1996;111:580-6.

21. Colombel J-F, Grandbastian B, Gower-Rousseau C, et al. Clinical characteristics of Crohn's disease in 72 families. Gastroenterology 1996;111:604-7.

22. Satsangi J, Rosenberg WMC, Jewell DP. The prevalence of inflammatory bowel disease in relatives of patients with Crohn's disease. Eur J Gastroenterol Hepatol 1994;6:413-6.

23. Orholm M, Munkolm P, Langholz E, Nielsen OH, Sorensen TI, Binder V. Familial occurrence of inflammatory bowel disease. N Engl J Med 1991;324:84-8.

24. Peeters M, Nevens H, Baert F, et al. Familial aggregation in Crohn's disease: increased age adjusted risk and concordance in clinical characteristics. Gastroenterology 1996;111:597-603.

25. Risch N. Linkage strategies for genetically complex traits. II. The power of affected relative pairs. Am J Hum Gen 1990;46:229-41.

26. Bayless TM, Tokayer AZ, Polito JM, Quaskey SA, Mellits ED, Harris ML. Crohn's disease: concordance for site and clinical type in affected family members - potential heriditary influences. Gastroenterology 1996;111:573-9.

27. Satsangi J, Grootscholten C, Holt H, Jewell DP. Clinical patterns of familial inflammatory bowel disease. Gut 1996;38:738-41.

28. Lee JCW, Lennard-Jones JE. Inflammatory bowel disease in 67 families each with 3 or more affected first-degree relatives. Gastroenterology 1996;111:587-96.

29. Polito JM, Rees RC, Childs B, Mendeloff AI, Harris ML, Bayless TM. Preliminary evidence for genetic anticipation in Crohn's disease. Lancet 1996;347:798-800.

30. Tysk C, Lindberg E, Järnerot G, Flodérus-Myrhed B. Ulcerative colitis and Crohn's disease in an unselected population of monozygotic and dizygotic twins. A study of heritability and the influence of smoking. Gut 1988;29:990-6.

31. Thompson NP, Driscoll R, Pounder RE, Wakefield AJ. Genetics versus environment in inflammatory bowel disease: results of a British twin study. BMJ 1996;312:95-6.

32. Orholm M, Binder V, Sorenson T, Kyvik K. Inflammatory bowel disease in a Danish twin register. Gut 1196;39:A187. (Abst 1071)

33. Breslin N, Todd A, Kilgallen C, O'Morain C. Monozygotic twins with Crohn's disease and ulcerative colitis: A unique case report. Gut 1997;41:557-60.

34. Monsen U, Iselius L, Johansson C, Hellers G. Evidence for a major additive gene in ulcerative colitis. Clin Genet 1989;36:411-4.

35. Orholm M, Iselius L, Sorensen TI, Munkholm P, Langholz E, Binder V. Investigations of inheritance of chronic inflammatory bowel disease by complex segregation analysis. BMJ 1993;306:20-4.

36. Kuster W, Pascoe L, Purrman J, Funk S, Majewski F. The genetics of 
Crohn's disease: complex segregation analysis of a family study with 265 patients with Crohn's disease and 5387 relatives. Am J Genet 1989;32:105-8

37. Yang $\mathrm{H}$, Shohat $\mathrm{T}$, Rotter J. The Genetics of inflammatory bowel disease. In: McDermott R, Stenson W, eds. Current Topics in Gastroenterology: Inflammatory Bowel Disease. New York: Elsevier, 1992:17-51.

38. Satsangi J, Parkes M, Louis E, et al. Two-stage genome-wide search in inflammatory bowel disease: evidence for susceptibility loci on chromosomes 3, 7 and 12. Nature Genetics 1996;14:199-202.

39. Hampe J, Schreiber S, Shaw SH, et al. A genomewide analysis provides evidence for novel linkages in inflammatory bowel disease in a large European cohort. Am J Hum Genet 1999;64:808-16.

40. Calkins BM. A meta-analysis of the role of smoking in inflammatory bowel disease. Dig Dis Sci 1989;34:1841.

41. Jeejeebhoy KN. Nutritional aspects of inflammatory bowel disease. In: Kirsner JB, Shorter RB, eds. Inflammatory Bowel Disease. Baltimore: Williams and Wilkins, 1995:734-9.

42. Wakefield AJ, Pittilo RM, Sim R, et al. Evidence of persistent measles virus in Crohn's disease. J Med Virol 1993;39:345-53.

43. Fiocchi C, Hilfiker M. Interleukin 2 activity of human intestinal mucosa mononuclear cells. Decreased levels in inflammatory bowel disease. Gastroenterology 1984;86:734-42.

44. Weber JL. Informativeness of human (dC-dA)n. (dG-dT)n polymorphisms. Genomics 1990;7:524-30.

45. Lander ES, Kruglyak L. Genetic dissection of complex traits: guidelines for interpreting and reporting linkage results. Nature Genetics 1995;11:241-7.

46. Hugot JP, Laurent-Puig P, Gower-Rousseau C, et al. Mapping of a susceptibility locus for Crohn's disease on chromosome 16. Nature 1996;379:821-3.

47. Lesage S, Hugot J, Colombel J, et al. Linkage analysis of chromosome 12 loci in Crohn's disease families. Gastroenterology 1999;116:A740. (Abst G3212)

48. Parkes M, Satsangi J, Merriman A, Jewell DP. Precision mapping of chromosome 12 linkage in IBD: evidence of a haplotype association. Gastroenterology 1998;114(Suppl 2):A1058. (Abst G4322)

49. Ohmen JD, Yang H, Yamomoto KK, et al. Susceptibility locus for inflammatory bowel disease on chromosome 16 has a role in Crohn's disease but not in ulcerative colitis. Hum Mol Gen 1996;5:1679-83.

50. Yang H, Ohmen J, Ma R, et al. Linkage and association between Crohn's disease and a putative locus on chromosome 12. Gastroenterology 1998;114(Suppl 2):G4581. (Abst)

51. Cavanaugh JA, Callen DF, Wilson SR, et al. Analysis of Australian Crohn's disease pedigrees refines the localization for susceptibility to inflammatory bowel disease on chromosome 16. Ann Hum Gen 1998;62:291-8.

52. Xu J, Meyers D, Pericak-Vance M. Lod Score Analysis. In: Haines J, Pericak-Vance M, eds. Approaches to Gene Mapping in Complex Human Disease. New York: Wiley-Liss, 1998:253-72.

53. Mirza MM, Lee J, Teare D, et al. Evidence of linkage of the inflammatory bowel disease susceptibility locus on chromosome 16 (IBD1) to ulcerative colitis. J Med Genet 1998;35:218-21.

54. Duerr RH, Barmada MM, Zhang L, et al. Linkage and association between inflammatory bowel disease and a locus on chromosome 12. Am J Hum Genet 1998;63:95-100.

55. Speer M. Sample Size and Power. In: Haines J, Pericak-Vance M, eds. Approaches to Gene Mapping in Complex Human Disease. New York: Wiley-Liss, 1998:161-200.

56. Duerr R, Zhang L, Ford M, Chensny L. Further evidence for linkage between Crohn's disease and a locus on chromosome 7. Gastroenterology 1999;116(Suppl 2):A703. (Abst G3057)

57. Akolkar P, Gulwani B, Lin X, Danzi S, Terwilliger J, Silver J. Fine mapping of regions linked to Crohn's disease on chromosomes 12 and 16. Am J Hum Genet 1998;63:A279. (Abst A279)

58. Rioux JD, Daly MJ, Green T, et al. Absence of linkage between inflammatory bowel disease and selected loci on chromosomes 3, 7, 12 and 16. Gastroenterology 1998;115:1062-5.

59. Vermeire S, Peeters M, Vlietinck R, et al. No evidence for linkage to chromosomes 16,12,7 and 3 in the Belgian population may reflect genetic heterogeneity of IBD. Digestion 1998;59(Suppl 3):132. (Abst FoLM1282)

60. Cho JH, Nicolae DL, Gold LH, et al. Identification of novel susceptibility loci for inflammatory bowel disease on chromosomes 1p, 3q and $4 \mathrm{q}$ : evidence for epistasis between $1 \mathrm{p}$ and IBD1. Proc Nat Acad Sci USA 1998;95:7502-7.

61. Brant S, LaBuda M, Lee S, et al. Younger age of diagnosis identifies families with greater linkage evidence for IBD loci on chromosomes 1p, 3q and 16. Gastroenterology 1999;116:A673. (Abst G2932).
62. Hayward P, Satsangi J, Jewell DP. Inflammatory bowel disease and the $X$ chromosome. Q J Med 1996;89:713-8.

63. Price WH. A high incidence of chronic inflammatory bowel disease in patients with Turner's syndrome. J Med Genet 1979;16:263-6.

64. Arulanantham K, Kramer MS, Gryboski JD. The association of inflammatory bowel disease and X chromosomal abnormality. Paediatrics 1980;66:63-7.

65. Kohler JA, Grant DB. Crohn's disease in Turner's syndrome. BMJ 1981;282:950.

66. Scarpa R, Lubrano E, Castiglione F, Morace F, Ames PR, Oriente P. Juvenile rheumatoid arthritis, Crohn's disease and Turner's syndrome: a novel association. Clin Exp Rheumatol 1996;14:449-50. (Lett)

67. Manzione NC, Kram M, Kram E, Das KM. Turner's syndrome and inflammatory bowel disease: a case report with immunologic studies. Am J Gastroenterol 1988;83:1294-7.

68. Vermeire S, Satsangi J, Peeters M, Parkes M, Jewell D, Rutgeerts P. Susceptibility locus on short arm of the X chromosome in IBD. Digestion 1998;1998:14. (Abst GaPP0043)

69. Strachan T, Read A. Human Molecular Genetics. Oxford: BIOS Scientific Publishers Limited, 1996:596.

70. Risch N, Merikangas K. The future of genetic studies of human complex diseases. Science 1996;273:1516-7.

71. Spielman RS, McGinnis RE, Ewens WJ. Transmission test for linkage disequilibrium: the insulin gene region and insulin-dependent diabetes mellitus (IDDM). Am J Hum Gen 1993;52:506-16.

72. Spielman RS, Ewens WJ. The TDT and other family-based tests for linkage disequilibrium and association. Am J Hum Genet 1996;59:983-9.

73. Deloukas P, Schuler GD, Gyapay G, et al. A physical map of 30,000 human genes. Science 1998;282:744-6.

74. Deloukas P, Schuler GD, Gyapay G, et al. A new gene map of the human genome ttp://www.ncbi.nlm.nih.gov/genemap98/, 1998.

75. Hampe J, Hermann B, Bridger S, MacPherson AJ, Mathew CG, Schreiber $S$. The interferon-gamma gene as a positional and functional candidate gene for inflammatory bowel disease. Int J Colorectal Dis 1998;13:260-3.

76. Simmons J, Mullighan C, Welsh K, Jewell D. Vitamin D receptor gene polymorphism: further evidence for an association with Crohn's disease. Gastroenterology 1998;114:A1086. (Abst G4446).

77. Stokkers P, Huibregtse KJ, Reitsma P, Tytgat G, Vandeventer S. Analysis of a positional candidate gene for inflammatory bowel disease. Gastroenterology 1999;116(Suppl 2):A825. (Abst G3579).

78. Hugot J, Zouali H, Colombel J, et al. Mutation screening in the CD19 and CD43 (sialophorin) genes in Crohn's disease patients. Gastroenterology 1999;16(Suppl 2):A740. (Abst G3213)

79. Satsangi J, Welsh KI, Bunce M, et al. Contribution of genes of the major histocompatibility complex to susceptibility and disease phenotype in inflammatory bowel disease. Lancet 1996;347:1212-7.

80. Mathew CG, Easton D, Lennard-Jones JE. HLA and inflammatory bowel disease. Lancet 1996;348:68.

81. Hugot JP, Laurent-Puig P, Gower-Rousseau C, et al. Linkage analyses of chromosome 6 loci, including HLA, in familial aggregations of Crohn's disease. Am J Med Genetics 1994;52:207-13.

82. Bouma G, Crusius JB, Garcia-Gonzalez MA, et al. Genetic markers in clinically well defined patients with ulcerative colitis (UC). Clin Exp Immunol 1999;115:294-300.

83. Roussomoustakaki M, Satsangi J, Welsh KI, et al. Genetic markers may predict disease behaviour in patients with ulcerative colitis. Gastroenterology 1997;112:1845-53.

84. Toyoda H, Wang S-J, Yang H, et al. Distinct association of HLA Class II genes with inflammatory bowel disease. Gastroenterology 1993;104:741-8.

85. Duerr RH, Neigut DA. Molecularly defined HLA-DR2 alleles in ulcerative colitis and an anti-neutrophil cytoplasmic antibody-positive subgroup. Gastroenterology 1995;108:423-7.

86. Bioque G, Bouma G, Crusius JBA, et al. Evidence for genetic heterogeneity in IBD: 1 . The interleukin-1 receptor antagonist in the predisposition to suffer from ulcerative colitis. Eur J Gastroenterol Hepatol 1996;8:105-10.

87. McConnell R. Ulcerative colitis - genetics feature. Scand J Gastroenterol 1983;18:14.1.

88. Smolen JS, Gangl A, Polterauer P, Menzel EJ, Mayr WR. HLA antigens in inflammatory bowel disease. Gastroenterology 1982;82:34-8.

89. Mehal WZ, Lo YD, Wordsworth BP, et al. HLA DR4 is a marker for rapid disease progression in primary sclerosing cholangitis. Gastroenterology 1994;106:160-7.

90. Zetterquist H, Broome U, Einarsson K, Olerup O. HLA class II genes in primary sclerosing cholangitis and chronic inflammatory bowel disease: no HLA-DRw52a association in Swedish patients with sclerosing cholangitis. Gut 1992;33:942-6. 
91. Cottone M, Bunce M, Taylor C, Ting A, Jewell D. Ulcerative colitis and HLA phenotype. Gut 1985;26:952-4.

92. Asakura H, Tsuchiya M, Aiso S, et al. Association of the human leukocyte DR2 antigen with Japanese ulcerative colitis. Gastroenterology 1982;82:413-8.

93. Futami S, Aoyama N, Honsako Y, et al. HLA-DRB1*1502 allele, subtype of DR15, is associated with susceptibility to ulcerative colitis and its progression. Dig Dis Sci 1995;40:814-8.

94. Sugimura K, Asakura H, Mizuki N, et al. Analysis of genes within the HLA region affecting susceptibility to ulcerative colitis. Hum Immunol 1993;36:112-8.

95. Masuda H, Nakamura Y, Tanaka T, Hayakawa S. Distinct relationship between HLA-DR genes and intractability of ulcerative colitis. Am J Gastroenterol 1994;89:1957-62.

96. Uyar FA, Imeryuz N, Saruhan-Direskeneli G, et al. The distribution of HLA-DRB alleles in ulcerative colitis patients in Turkey. Eur J Immunogenet 1998;25:293-6.

97. Yang H, Plevy S, Taylor K, et al. Linkage of Crohn's disease to the major histocompatibility region is detected by multiple non-parametric analyses. Gut 1999;44:519-26.

98. Danze P-M, Colombel J-F, Jacquot S, et al. Association of HLA Class II genes with susceptibility to Crohn's disease. Gut 1996;39:69-72.

99. Reinshagen M, Loeliger C, Kuehni P, et al. HLA Class II gene frequencies in Crohn's disease: a population based analysis in Germany. Gut 1996;38:538-42.

100. Forcione DG, Sands B, Isselbacher KJ, Rustgi A, Podolsky DK, Pillai S. An increased risk of Crohn's disease in individuals who inherit the HLA class II DRB3*0301 allele. Proc Natl Acad Sci USA 1996;93:5094-8.

101. Cariappa A, Sands B, Forcione D, Finkelstein D, Podolsky DK, Pillai S. Analysis of MHC class II DP, DQ and DR alleles in Crohn's disease. Gut 1998;43:210-5

102. Heresbach D, Alizadeh M, Bretagne J. Investigation of the association of major histocompatibility complex genes, including HLA Class I, Class II and TAP genes, with clinical forms of Crohn's disease. Eur J Immunogenet 1996;23:141-51.

103. Bouma G, Poen AC, Garcia-Gonzalez MA, et al. HLA-DRB1*03, but not the TNF -308 promoter gene polymorphism, confers protection against fistulising Crohn's disease. Immunogenetics 1998;47:451-5.

104. Nakajima A, Matsuhashi N, Kodoma T, Yazaki Y, Takazoe M, Kimura A. HLA-linked susceptibility and resistance genes in Crohn's disease. Gastroenterology 1995;109:1462-7.

105. Orchard TR, Wordsworth BP, Jewell DP. Peripheral arthropathies in inflammatory bowel disease: their articular ditribution and natural history. Gut 1998;42:387-91.

106. Orchard TR, Thiyagaraja S, Walsh KI, Wordsworth BP, Jewell DP. HLA genes are important phenotype determining genes in the peripheral arthropathies of IBD. Gastroenterology 1998;114:A1056. (Abst G4321)

107. Stokkers P, Reitsma P, Tytgat G, van Deventer S. HLA-DR phenotypes and inflammatory bowel disease: a meta-analysis. Gastroenterology 1999;116:A825. (Abst G3580)

108. Mansfield JC, Holden $\mathrm{H}$, Tarlow JK, et al. Novel genetic association between ulcerative colitis and the anti-inflammatory cytokine interleukin-1 receptor antagonist. Gastroenterology 1994;106:637-42.

109. Louis E, Satsangi J, Roussomoustakaki M, et al. Cytokine gene polymorphisms in inflammatory bowel disease. Gut 1996;39:705-10.

110. Hacker UT, Gomolka M, Keller E, et al. Lack of association between an interleukin-1 receptor antagonist gene polymorphism and ulcerative colitis. Gut 1997;40:623-7.

111. Heresbach D, Alizadeh M, Dabadie A, et al. Significance of interleukin-1beta and interleukin-1 receptor antagonist genetic polymorphism in inflammatory bowel diseases. Am J Gastroenterol 1997;92:1164-9.

112. Yang H, Vora DK, Targan SR, Toyoda H, Beaudet AL, Rotter JI. Intercellular adhesion molecule 1 gene associations with immunologic subsets of inflammatory bowel disease. Gastroenterology 1995;109:440-8.

113. Bellamy R, Ruwende C, Corrah T, McAdam KPWJ, Whittle HC, Hill AVS. Variations in the NRAMP1 gene and susceptibility to tuberculosis in West Africans. N Engl J Med 1998;338:640-4.

114. Hofmeister A, Neibergs HL, Pokorny RM. The natural resistance-associated macrophage protein gene is associated with Crohn's disease. Surgery 1997;122:173-8.

115. Bachvarov DR, Landry M, Houle S, Pare P, Marceau F. Altered frequency of a promoter polymorphic allele of the kinin B1 receptor gene in inflammatory bowel disease. Gastroenterology 1998;115:1045-8.

116. Targan SR, Hanauer SB, van Deventer SJ, et al. A short-term study of chimeric monoclonal antibody cA2 to tumor necrosis factor alpha for Crohn's disease. Crohn's Disease cA2 Study Group. N Engl J Med 1997;337:1029-35.
117. Bouma G, Crusius JB, Oudkerk Pool M, et al. Secretion of tumour necrosis factor alpha and lymphotoxin alpha in relation to polymorphisms in the TNF genes and HLA-DR alleles. Relevance for inflammatory bowel disease. Scand J Immunol 1996:43:456-63.

118. Bouma G, Xia B, Crusius JBA, et al. Distribution of four polymorphisms in the tumour necrosis factor (TNF) genes in patients with inflammatory bowel disease (IBD). Clin Exp Immunol 1996;103:391-6.

119. Plevy SE, Targan SR, Yang H, Fernandez D, Rotter JI, Toyoda H. Tumor necrosis factor microsatellites define a Crohn's disease-associated haplotype on chromosome 6. Gastroenterology 1996;110:1053-60.

120. Heresbach D, Ababou A, Bourienne A, et al. [Polymorphism of the microsatellites and tumor necrosis factor genes in chronic inflammatory bowel diseases]. Gastroenterol Clin Biol 1997;21:555-61.

121. Heresbach D, Alizadeh M, Bretagne JF, et al. TAP gene transporter polymorphism in inflammatory bowel diseases. Scand J Gastroenterol 1997;32:1022-7.

122. Orchard T, Vaughan R, Simmons J, Welsh K, Jewell D. MHC class I like gene-A (MICA) is associated with ulcerative colitis but not Crohn's disease. Gastroenterology 1999;116:A7. (Abst G3423)

123. Simmons J, Marshall S, Welsh K, Jewell D. C-C Chemokine receptor 5 polymorphism in inflammatory bowel disease. Gastroenterology 1999;116:A821 (Abst G3561)

124. Kyo K, Parkes M, Takei Y, et al. Association of ulcerative colitis with rare VNTR alleles of the human intestinal mucin gene, MUC3. Hum Mol Genet 1999;8:307-11

125. Mahler M, Bristol IJ, Sundberg JP, et al. Genetic analysis of susceptibility to dextran sulfate sodium-induced colitis in mice. Genomics 1999;55:147-56.

126. Mombaerts P, Mizoguchi E, Grusby MJ, Glimcher LH, Bhan AK, Tonegawa S. Spontaneous development of inflammatory bowel disease in T-cell receptor mutant mouse. Cell 1993;175:275-82.

127. Kuhn RG, Lohler J, Rennick D, Rajewsky K, Muller W. Interleukin 10 deficient mice develop chronic enterocolitis. Cell 1993;75:263-74.

128. Sadlack B, Merz H, Schorle H, Schimpl A, Feller AC, Horak I. Ulcerative colitis-like disease in mice with a disrupted interleukin 2 gene. Cell 1993;75:253-61.

129. Watanabe M, Ueno Y, Yajima T, et al. Interleukin 7 transgenic mice develop chronic colitis with decreased interleukin 7 protein accumulation in the colonic mucosa. J Exp Med 1998; 187:389-402.

130. Podolsky DK. Lessons from genetic models of inflammatory bowel disease. Acta Gastroenterol Belg 1997;60:163-5.

131. Rudolph U, Finegold MJ, Rich SS, et al. Ulcerative colitis and adenocarcinoma of the colon in Gai2-deficient mice. Nature Genetics 1995;10:143-9.

132. Ehrhardt R, Ludviksson B, Gray B, Neurath M, Stober W. Induction and prevention of colonic inflammation in IL-2 deficient mice. J Immunol 1997;158:566-73.

133. Kruglyak L, Lander ES. Limits on fine mapping of complex traits. Am J Hum Genet 1996;58:1092-3. (Lett)

134. Curran ME, Lau KF, Hampe J, et al. Genetic analysis of inflammatory bowel disease in a large European cohort supports linkage to chromosomes 12 and 16. Gastroenterology 1998;115:1066-71.

135. Kruglyak L, Lander ES. High-resolution genetic mapping of complex traits. Am J Hum Genet 1995;56:1212-23.

136. Cavanaugh J. IBD Consortium Genetic Analysis Home Page ttp://pride.anu.edu.au/ ibd/index.html, 1999.

137. SNP attack on complex traits. Nat Genet 1998;20:217-8.

138. Wang D, Fan J, Siao C, et al. Large-scale identification, mapping, and genotyping of single-nucleotide polymorphisms in the human genome. Science 1998;280:1077-82.

139. To affinity... and beyond! Nat Genet 1996;14:367-70.

140. Bonn D. International consortium SN(i)Ps away at individuality. Lancet 1999:353:1684.

141. Zhao LP, Aragaki C, Hsu L, Quiaoit F. Mapping of complex traits by single-nucleotide polymorphisms. Am J Hum Genet 1998;63:225-40.

142. Colombel J, Lille C, Touze I, et al. Genotypic analysis of the thiopurine s-methyltransferase (TPMT) gene in patients with Crohn's disease and severe myelosuppresion during azathioprine therapy. Gastroenterology 1999;116:A688. (Abst G2996)

143. Parkes M, Satsangi J, Lathrop GM, Bell JI. Susceptibility loci in inflammatory bowel disease. Lancet 1996;348:1588. (Lett)

144. Brant SR, Fu Y, Fields CT, et al. American families with Crohn's disease have strong evidence for linkage to chromosome 16 but not chromosome 12. Gastroenterology 1998;115:1056-61. 


\section{ERRATA}

The following errors appeared in the article, "Inflammatory bowel disease: Progress toward a gene" (2000;14[3]:207-218).

On page 208, under the heading "Twin studies", the sentence, "In the UC group, one of 18 monozygotic and none of $20 \mathrm{di}$ zygotic or unknown twins were concordant..." should have read "...one of 16 monozygotic and none of 20 dizygotic or...". Later in the same paragraph, the sentence "Combining these data gave overall UC mono- and dizygotic concordance rates of $7 \%$ and $2 \%$, respectively...", should have read, "...concordance rates of $13 \%$ and $2 \%$, respectively. The errors are regretted. 


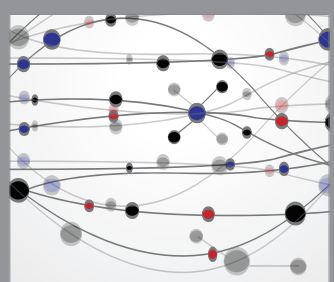

The Scientific World Journal
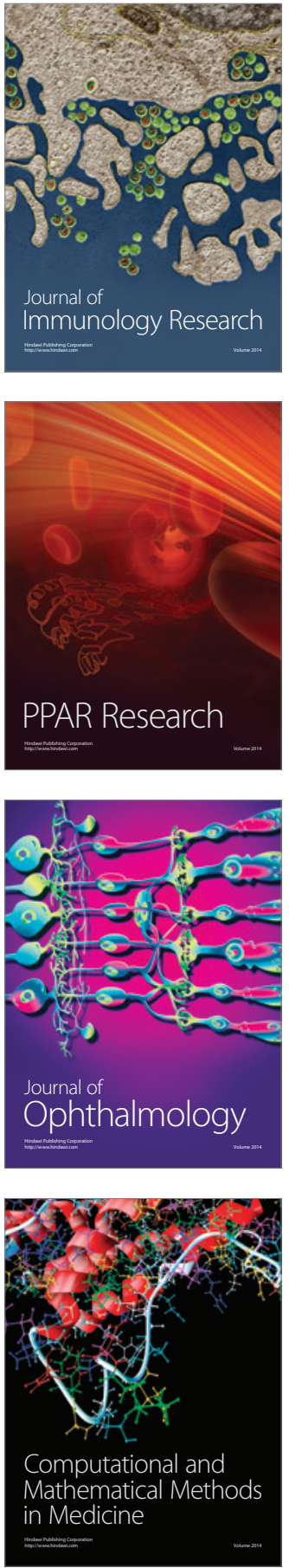

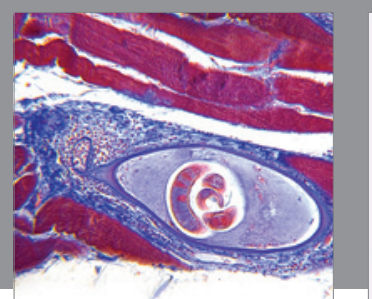

Gastroenterology Research and Practice

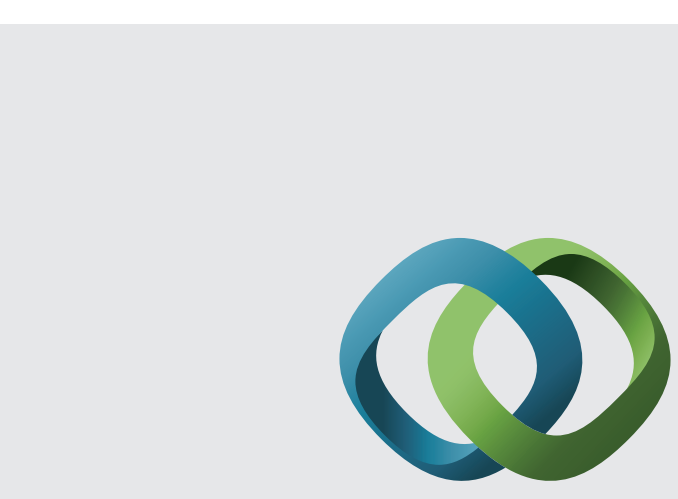

\section{Hindawi}

Submit your manuscripts at

http://www.hindawi.com
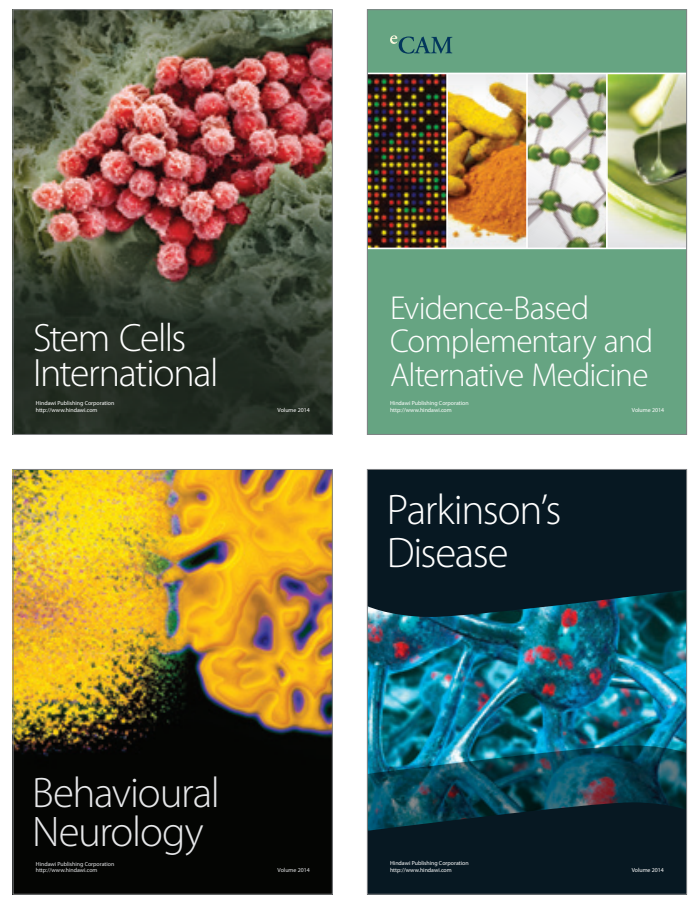
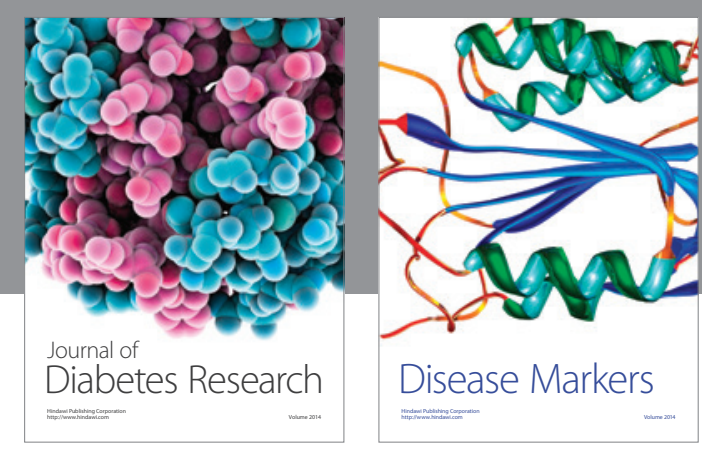

Disease Markers
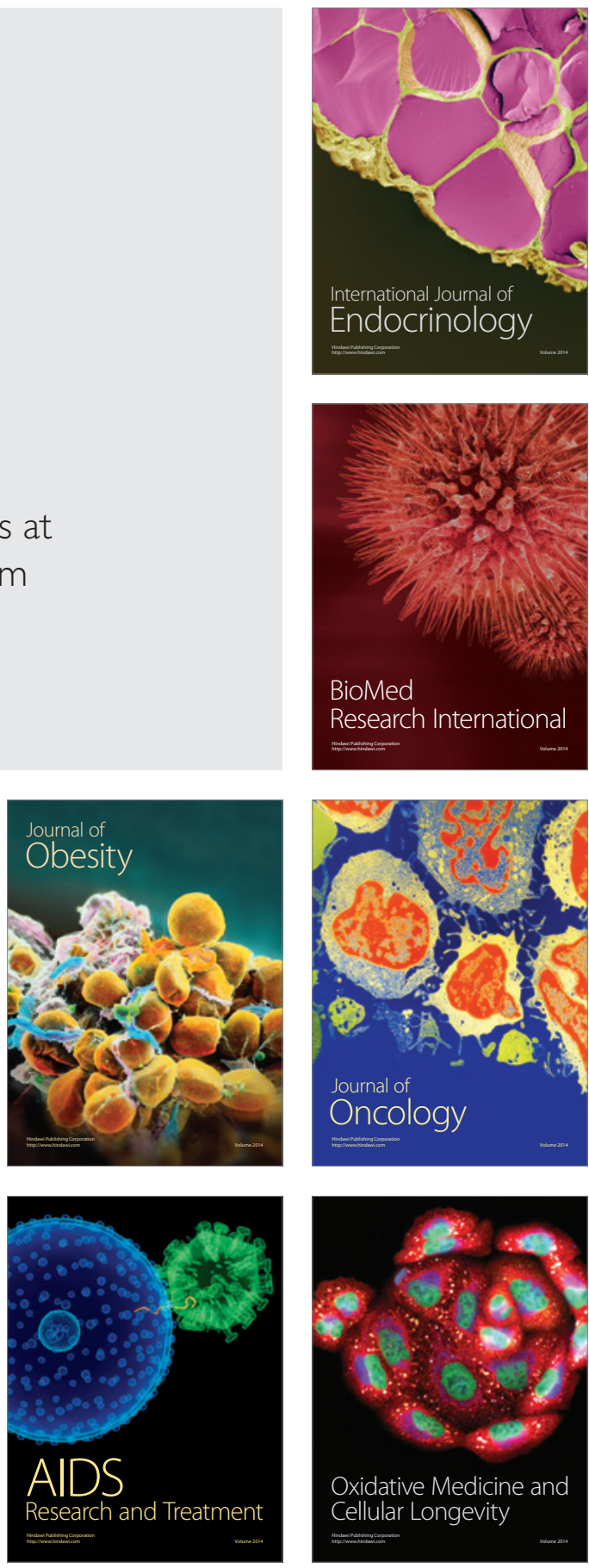